\title{
PENGARUH PEER TEACHING BERBANTUAN APLIKASI SPSS TERHADAP KEMAMPUAN PENGUASAAN KONSEP PADA MATERI STATISTIKA
}

\author{
Nurhayati \\ FKIP Universitas Almuslim Aceh \\ nurhayati09.nur@gmail.com
}

\begin{abstract}
Abstrak
Penelitian ini termasuk kedalam penelitian kuantitatif dengan metode yang diterapkan adalah ex post facto dan jenis penelitiannya berupa quasi experiment. Tujuan dari penelitiannya yaitu untuk mengetahui pengaruh dari peer teaching berbantuan aplikasi SPSS terhadap kemampuan penguasaan konsep pada materi statistika. Dalam pembelajaran matematika, guru diharuskan untuk berpedoman terhadap bagaimana cara mengajar itu sendiri supaya siswa dapat mengikuti kegiatan pembelajaran dengan baik. Akan tetapi pada kenyataannya kebanyakan guru masih menggunakan pembelajaran klasikal. Statistika adalah materi matematika yang menjadikan siswa kesulitan untuk memahaminya. Hal itu terungkap berdasarkan hasil observasi dengan salah satu guru matematika di SMAN 1 Bireuen yang menunjukkan bahwa $60 \%$ siswa menghadapi kesulitan untuk menyelesaikan masalah pada materi statistika. Peer teaching berbantuan aplikasi SPSS memiliki pengaruh dalam kegiatan pembelajaran. Peer teaching yaitu suatu model atau metode pembelajaran yang menjadikan siswa sebagai pemeran utama, dimana siswa akan melakukan proses belajar dari siswa lain sehingga siswa lebih mudah memahami apabila mengalami kesulitan. Pembelajaran dengan menggunakan peer teaching guru bertindak sebagai pembimbing dan pengatur proses pembelajaran. Adapun hasil penelitian ini menyatakan bahwa nilai signifikansi sebesar $0.00<0.05$ maka $H_{0}$ ditolak, artinya terdapat pengaruh antara peer teaching berbantuan aplikasi SPSS terhadap kemampuan penguasaan konsep pada materi statistika
\end{abstract}

Kata Kunci: Peer Teaching, SPSS, Statistika.

\begin{abstract}
This research is a quantitative research with the method applied is ex post facto and the type of research is a quasi experiment. The purpose of his research is to determine the effect of peer teaching assisted by SPSS applications on the ability to master concepts in statistical material. In learning mathematics, teachers are required to be guided by how to teach themselves so that students can participate in learning activities properly. But in reality most teachers still use classical learning. Statistics is a mathematical material that makes it difficult for students to understand it. This was revealed based on the results of observations with one of the mathematics teachers at SMAN 1 Bireuen which showed that 60\% of students had difficulty solving problems in statistics material. Peer teaching assisted by the SPSS application has an influence on learning activities. Peer teaching is a learning model or method that makes students the main actors, where students will carry out the learning process from other students so that students understand more easily when they experience difficulties. Learning by using peer teaching, the teacher acts as a guide and regulator of the learning process. The results of this study state that the significance value is $0.00<0.05$ then $H_{0}$ is rejected, meaning that there is an influence between peer teaching assisted by the SPSS application on the ability to master concepts in statistical material.
\end{abstract}

Keywords: Peer Teaching, SPSS, Statistics. 


\section{PENDAHULUAN}

Matematika merupakan mata pelajaran eksak yang dapat memberi pengaruh dalam membentuk karakter siswa. Hal ini dikarenakan matematika merupakan suatu proses berpikir dalam menyelesaikan permasalahan secara sistematis dan logis. Menurut Nurhayati dan Wahyuni [1] matematika pada dasarnya bukan hanya mencakup rumus saja dan menggunakan rumus tersebut dalam menyelesaikan soal. Tetapi, matematika memiliki fungsi yang penting dalam mengaplikasikan kemampuan dalam berpikir kritis serta kreatif. Oleh sebab itu, dalam kegiatan pembelajaran matematika diperlukan suatu konsep, model, atau metode pembelajaran yang bervariasi sehingga matematika tidak dianggap lagi sebagai pelajaran yang sulit tetapi mudah dan menyenangkan. Menurut Nurhayati dan Novianti [2] dalam kegiatan pembelajaran matematika, guru diharuskan untuk mampu menyesuaikan konsep dan kondisi siswa sehingga kegiatan pembelajaran yang dilakukan menjadi lebih aktif serta dapat meningkatkan nilai matematika siswa. Dalam pembelajaran khususnya matematika, guru diharuskan untuk berpedoman terhadap bagaimana cara mengajar itu sendiri sehingga mengakibatkan siswa dapat mengikuti proses belajar mengajar lebih baik. Akan tetapi, kenyataan yang sering dijumpai di sekolah - sekolah menunjukkan bahwa kebanyakan guru matematika masih menggunakan model atau metode pembelajaran klasikal. Akibatnya siswa merasa cepat bosan, tidak termotivasi dan tidak tertarik untuk mengikuti proses pelajaran tersebut. Hal ini akan menjadikan siswa pada aspek kemampuan penguaasaan konsep matematika menjadi rendah.

Rendahnya nilai matematika menyebabkan daya tarik siswa terhadap matematika berkurang. Dalam pembelajaran di sekolah, statistika adalah materi matematika yang menjadikan siswa kesulitan untuk memahaminya. Hal itu terungkap berdasarkan hasil observasi dengan salah satu guru matematika di SMAN 1 Bireuen yang menunjukkan bahwa 60\% siswa menghadapi kesulitan untuk menyelesaikan masalah pada materi statistika. Materi statistika merupakan materi yang dianggap sulit karena materi statistika terdapat banyak rumus dan butuh ketelitian dalam mengerjakan soal. Hal ini terbukti berdasarkan nilai tes harian dan ulangan semester, siswa masih banyak yang mendapatkan nilai dibawah standar ketuntasan minimal. Selain itu, siswa juga sering kali diadakan remedial setelah diadakan tes harian pada materi statistika. Materi statistika menjadi materi yang sulit bagi siswa sehingga membuat siswa kurang bersemangat ketika proses pembelajaran berlangsung.

Menurut Riyanto dan Nugrahanti [3] adanya anggapan negatif mengenai materi statistika perlu dihilangkan dan siswa harus mengubah pola pikirnya. Untuk mengubah pola pikir siswa tersebut maka dapat diterapkan suatu aplikasi yang memberi kemudahan dalam menyelesaikan persoalan dalam materi statistika, salah satunya yaitu SPSS. Hal tersebut sesuai dengan pernyataan yang diberikan oleh Hayat, Syaipul, Anggraini, dan Redjeki [4], dengan adanya SPSS siswa diberikan kesempatan untuk mengembangkan cara menganalisis suatu permasalahan dan menemukan sendiri proses pemahaman dari suatu konsep sehingga siswa akan semakin aktif dalam interaksi dikelas. SPSS merupakan sebuah aplikasi yang dapat dimanfaatkan siswa dalam menghitung angka-angka yang rumit dalam materi statistika. SPSS bukan sebuah model pembelajaran tetapi merupakan aplikasi yang 
dapat menjadikan pekerjaan lebih cepat dan akurat sehingga akan menjadikan proses belajar mengajar menjadi lebih bermakna.

Persolan diatas dapat diatasi apabila guru mampu menerapkan model atau metode pembelajaran dalam proses belajar mengajar yang dapat menjadikan siswa lebih aktif, berpikir kritis serta mempunyai kemampuan dalam bekerja sama antar teman. Adapun model atau metode yang dapat diterapkan yaitu model tutor sebaya (peer teaching) berbantuan aplikasi SPSS. Peer teaching dapat dikatakan sebagai model atau metode pembelajaran untuk menunjang kebutuhan siswa dimana antar sesama siswa dibina rasa untuk saling mengerti dan berbagi. Pada saat siswa belajar bersama teman sebayanya maka siswa akan berkonsentrasi kemudian dapat mengembangkan kemampuan untuk mendengarkan penjelasan tutor sebaya. Penerapan peer teaching sangat baik diterapkan dalam kegiatan pembelajaran. Selain menggunakan pembelajaran yang aktif melibatkan siswa, perlu adanya suatu kolaborasi model atau metode pembelajaran seperti tutor sebaya dengan aplikasi SPSS. Jadi dapat disimpulkan bahwa peer teaching yaitu suatu model atau metode pembelajaran yang menjadikan siswa sebagai pemeran utama, dimana siswa akan melakukan proses belajar dari siswa lain sehingga siswa lebih mudah memahami apabila mengalami kesulitan. Pembelajaran dengan menggunakan peer teaching guru bertindak sebagai pembimbing dan pengatur proses pembelajaran.

Peer teaching merupakan pembelajaran kelompok biasa tetapi siswa yang memilki nilai bagus dalam kelas dituntut untuk mengajari siswa yang dianggap masih kurang kemampuannya untuk memahami materi yang diberikan, kemudian siswa yang dianggap masih kurang kemampuannya di haruskan atau dipaksa untuk bertanya tentang materi yang belum dimengerti. Hal ini sejalan dengan penelitian dari Komang [5] menyatakan bahwa peer teaching yaitu teman sebaya dimana yang lebih paham materi memberikan bantuan kepada temannya. Hal ini dikarenakan bahasa yang digunakan oleh teman sebaya mudah untuk dimengerti. Selain itu, dengan adanya teman sebaya maka tidak ada lagi rasa takut, malu, dan rendah diri dalam bertanya ataupun meminta bantuan. Menurut Ahdiyat dan Sarjaya [6] Peer teaching merupakan sebuah pembaharuan informasi dan pengembangan konsep pembelajaran. Hal ini dikarenakan terjadi interaksi sesama siswa dalam kelas sehingga akan tumbuh sikap jujur, kreatif, kerjasama, kritis, tenggang rasa, bertanggung jawab dan disiplin.

Beberapa hasil penelitian tentang peer teaching diantaranya, penelitian yang telah dilakukan oleh Ahdiyat dan Sarjaya [6]; Abineneo, Rowa, Rina dan Jagom [7]; Putra, Purwanti dan Khoiriyah [8] menyatakan bahwa ada pengaruh antara peer teaching dengan hasil belajar matematika, pengolahan data dan kemampuan pemecahan masalah. Kemudian, Pangerti [9] menyatakan bahwa pembelajaran dengan menggunakan peer teaching dapat memberikan pengaruh yang positif terhadap minat belajar, motivasi serta hasil belajar matematika. Selanjutnya penelitian dari Izzati [10] menunjukkan bahwa penerapan program remedial melalui peer teaching serta pengayaan sebagai salah satu alternatif sebagai upaya untuk meningkatkan dalam hasil belajar matematika. Dari beberapa penelitian tersebut belum ada yang mengkaji tentang pengaruh peer teaching berbantuan aplikasi SPSS terhadap kemampuan penguasaan konsep pada materi statistika. Penelitian ini memiliki tujuan yaitu untuk mengetahui pengaruh dari peer teaching berbantuan aplikasi SPSS terhadap kemampuan penguasaan konsep pada materi statistika. 


\section{METODE}

Metode yang digunakan yaitu ex post facto dengan jenis penelitian yaitu quasi experiment. Pada penelitian ini kemudian akan uji seberapa pengaruh peer teaching berbantuan aplikasi SPSS (variabel $\mathrm{X}$ ) terhadap kemampuan penguasaan konsep (variabel Y) pada materi statistika. Rancangan penelitian dengan menerapkan rancangan dari Setyanto [11] yaitu sebagai berikut;

TABEL 1. The One Shot Case Study

\begin{tabular}{cc}
\hline Pelakuan & Kemampuan Penguasaan Konsep \\
\hline $\mathrm{X}$ & $\mathrm{O}$ \\
\hline
\end{tabular}

Adapun yang menjadi populasi adalah seluruh siswa SMAN 1 Bireuen kelas 11 IPS tahun ajaran 2019/2020, sampel dipilih secara random dan terpilih kelas 11 IPS 3 dengan jumlah siswa sebanyak 28 orang. Instrumen yang digunakan berupa tes uraian yang diberikan setelah kegiatan pembelajaran dengan menerapkan peer teaching berbantuan aplikasi SPSS berakhir. Selanjutnya, akan dilakukan pengolahan data dengan menggunakan aplikasi SPSS. Uji yang akan dilakukan yaitu berupa pengujian terhadap normalitas dan homogenitas, kemudian uji kelinieran regresi dan hipotesis yang digunakan untuk melihat ada pengaruh atau tidak secara signifikan.

\section{HASIL DAN PEMBAHASAN}

Deskripsi dari hasil analisis data dari penelitian ini berdasarkan hasil tes uraian yang diberikan. Tes yang dilakukan yaitu tes sebelum dan sesudah digunakan peer teaching berbantuan aplikasi SPSS. Tes uraian yang diberikan sebanyak 10 soal dengan 6 soal dinyatakan sudah realibel. Keenam soal tersebut sudah mencakup indeks kesukaran $0.30<I K<0.70$ dan daya pembeda yaitu $D P<0.40$. Adapun hasil deskriptif statistik yaitu

TABEL 2. Analisis Deskriptif Statistik

\begin{tabular}{lcc}
\hline \multicolumn{1}{c}{ Statistik } & Sebelum & Sesudah \\
\hline $\mathrm{n}$ & 28 & 28 \\
\hline Min & 40 & 65 \\
\hline Max & 70 & 90 \\
\hline Mean & 50.76 & 77.83 \\
\hline Standar Deviasi & 12.88 & 9.54 \\
\hline
\end{tabular}

Berdasarkan Tabel 2 diperoleh nilai sebelum digunakanan peer teaching berbantuan aplikasi SPSS yaitu untuk nilai minimum 40, nilai maksimum 70, mean 50.76 dan standar deviasi 12.88 dan nilai sesudah digunakan peer teaching berbantuan aplikasi SPSS yaitu untuk nilai minimum 65 , nilai maksimum 90 , mean 77.83 dan standar deviasi 9.54. Dengan demikian, dapat dikatakan bahwa hasil tes sesudah digunakan peer teaching berbantuan aplikasi SPSS memiliki nilai mean yang lebih besar jika dibandingkan dengan hasil tes sebelum digunakanan peer teaching berbantuan aplikasi SPSS. Hal ini dapat dikatakan penggunaan peer 
teaching berbantuan aplikasi SPSS berpengaruh terhadap kemampuan penguasaan konsep pada materi statistika.

Pernyataan diatas dapat dibuktikan kebenarannya dengan dilakukannya pengujian hipotesis terhadap data tersebut. Data yang digunakan pada penelitian ini haya data yang berasal dari hasil tes uraian yang diberikan setelah kegiatan pembelajaran berakhir. Selanjutnya dari data tesebut akan dilakukan analisis dengan menggunakan aplikasi SPSS serta taraf signifikan 0.05. Adapun uji yang pertama dilakukan yaitu uji normalitas, pengujian ini dilakukan untuk memperoleh informasi data tersebut sudah berdistribusi atau belum dengan mengunakan uji kolmogorov smirnov. Hasil dari pengujian normalitas adalah sebagai berikut;

TABEL 3. Uji Normalitas

\begin{tabular}{ccc}
\hline \multirow{2}{*}{ Data } & \multicolumn{2}{c}{ Kolmogorov Smirnov } \\
\cline { 2 - 3 } & Statistic & Sig. \\
\hline Hasil Tes Kemampuan Penguasaan Konsep & 0.15 & 0.18 \\
\hline
\end{tabular}

Berdasarkan Tabel 3 terlihat bahwa hasil dari pengujian normalitas dengan menggunakan kolmogorov smirnov diperoleh nilai sig. sebesar 0.15 . Hal ini dapat dinyatakan nilai sig. $>0.05$ yang artinya data hasil tes kemampuan penguasaan konsep pada materi statistika sudah berdistribusi normal. Selanjutnya akan diuji homogenitas untuk melihat data sudah homogen atau belum, adapun hasilnya ditunjukkan pada tabel berikut.

TABEL 4. Uji Homogenitas

\begin{tabular}{cccc}
\hline Data & Lavene Statistic & Sig. & Keterangan \\
\hline Hasil Tes Kemampuan Penguasaan Konsep & 1.72 & 0.18 & Homogen \\
\hline
\end{tabular}

Berdasarkan Tabel 4 menunjukkan hasil dari pengujian homogenitas dengan menggunakan lavene statistic dan nilai sig. yang diperoleh yaitu 0.18 . Hal ini dapat dinyatakan bahwa nilai sig. $>0.05$ yang artinya data hasil tes kemampuan penguasaan konsep pada materi statistika juga sudah berdistribusi homogen. Setelah dilakukan pengujian normalitas dan homogenitas maka tahap selanjutnya yaitu pengujian kelinieran regresi, hal ini digunakan untuk melihat apakah persamaan regresi yang terbentuk sudah lineat atau belum. Bersarkan hasil perhitungan maka diperoleh nilai sig. adalah 0.00 yang artinya peer teaching berbantuan aplikasi SPSS dengan kemampuan penguasaan konsep pada materi statistika terdapat hubungan yang linear, hal ini dikarenakan nilai sig. $<0.05$. Karena memiliki hubungan atau terdapat pengaruhnya maka selanjutnya menganalisis koefisien regresi.

TABEL 5. Koefisien Regresi

\begin{tabular}{lccccc}
\hline \multirow{2}{*}{ Persamaan Regresi } & \multicolumn{2}{c}{ Unstandardized Coefficients } & \multirow{2}{*}{ Std. Error } & & \multirow{2}{*}{ Sig. } \\
\cline { 2 - 3 } & $\boldsymbol{B}$ & 7.79 & 4.65 & 0.00 \\
\hline Constant & 31.90 & 0.16 & 3.89 & 0.00 \\
\hline $\begin{array}{l}\text { Hasil Tes Kemampuan } \\
\text { Penguasaan Konsep }\end{array}$ & 0.588 & & & \\
\hline
\end{tabular}


Dari Tabel 5 diketahui bahwa nilai konstanta adalah 31.90 dan nilai dari hasil tes kemampuan penguasaan konsep adalah 0.588. Dengan demikian dapat dinyatakan persamaan regresinya adalah sebagai berikut;

$$
Y=31.90+0.588 X
$$

Berdasarkan rumus tersebut dapat disimpulkan, jika terdapat siswa yang tidak menggunakan peer teaching berbantuan aplikasi SPSS maka kemampuan penguasaan konsep pada materi statistika sebesar 31.90. Setelah itu, akan diuji kebaikan model yang sudah diperoleh tersebut untuk mengetahui persentase pengaruhnya.

TABEL 6. Uji Kebaikan Model

\begin{tabular}{ccccc}
\hline Model & R & R Square & Adjusted R Square & Std. Error of the Estimate \\
\hline 1 & $.513^{*}$ & .595 & .459 & 5.936 \\
\hline
\end{tabular}

Dari Tabel 6 diketahui nilai kebaikan modelnya atau nilai dari $\mathrm{R}$ square sebesar 0.595. Artinya kemampuan variabel $\mathrm{X}$ mempengaruhi variabel $\mathrm{Y}$ adalah $59,5 \%$ sedangkan $40.5 \%$ dipengaruhi untuk yang lain. Tahap selanjutnya yaitu pengujian hipotesis yang digunakan untuk mengetahui adanya pengaruh atau tidak dari peer teaching berbantuan aplikasi SPSS maka kemampuan penguasaan konsep pada materi statistika. Ketentuan yang digunakan dalam pengujian hipotesis yaitu: $H_{0}$ : Penerapan peer teaching berbantuan aplikasi SPSS tidak berpengaruh signifikan terhadap kemampuan penguasaan konsep pada materi statistika.

$H_{1}$ : Penerapan peer teaching berbantuan aplikasi SPSS berpengaruh signifikan terhadap kemampuan penguasaan konsep pada materi statistika.

Sedangkan kriteria yang digunakan yaitu $H_{0}$ akan diterima jika nilai sig. $>0.05$. Adapun hasil dari pengujian hipotesis dengan menggunakan uji t adalah

\begin{tabular}{|c|c|c|c|c|}
\hline & TABEL & otesis & & \\
\hline \multirow[b]{2}{*}{ Persamaan Regresi } & \multicolumn{2}{|c|}{ Unstandardized Coefficients } & \multirow[b]{2}{*}{$t$} & \multirow[b]{2}{*}{ Sig. } \\
\hline & $\boldsymbol{B}$ & Std. Error & & \\
\hline Constant & 31.90 & 7.79 & 4.65 & 0.00 \\
\hline $\begin{array}{l}\text { Hasil Tes Kemampuan } \\
\text { Penguasaan Konsep }\end{array}$ & 0.588 & 0.16 & 3.89 & 0.00 \\
\hline
\end{tabular}

Berdasarkan Tabel 7 maka diperoleh hasil pengujian hipotesisnya yaitu menunjukkan bahwa nilai signifikansi sebesar $0.00<0.05$ maka $H_{0}$ ditolak, hal ini berarti terdapat pengaruh signifikan dari peer teaching berbantuan aplikasi SPSS terhadap kemampuan penguasaan konsep pada materi statistika. Hasil penelitian ini menunjukkan bahwa terdapat pengaruh antara peer teaching berbantuan aplikasi SPSS terhadap kemampuan penguasaan konsep pada materi statistika. Hasil tes yang dilakukan menunjukkan adanya peningkatan kemampuan penguasaan konsep pada materi statistika. Hal ini terjadi karena dengan menerapkan peer teaching berbantuan aplikasi SPSS dapat menghilangkan kecanggungan, bahasa teman lebih mudah dimengerti, dan siswa yang belum mengerti tidak malu untuk menanyakan kesulitan yang sedang dihadapinya saat proses pembelajaran berlangsung. Temuan ini senada dengan penelitian yang telah dilakukan oleh Ahdiyat dan Sarjaya [6]; Abineneo, Rowa, Rina dan Jagom [7]; Putra, Purwanti dan Khoiriyah [8]; Pangerti [9] dan Izzati [10]. 


\section{KESIMPULAN}

Berdasarkan hasil dan pembahasan diatas maka dapat diambil kesimpulan bahwa adanya pengaruh yang signifikan dari peer teaching berbantuan aplikasi SPSS terhadap kemapuan penguasaan konsep pada materi statistika. Hal tersebut berdasarkan hasil dari pengujian hipotesis dengan menggunakan aplikasi SPSS. Penggunaan peer teaching berbantuan aplikasi SPSS dapat memberi pengaruh yang positif kepada siswa dalam meningkatkan kemampuan penguasaan konsep pada materi statistika karena proses pembelajaran yang dapat memotivasi siswa dan menyenangkan.

\section{DAFTAR RUJUKAN}

[1] Nurhayati \& Wahyuni, R. 2020. Penggunaan Model Discovery Learning Berbasis Media Interaktif Terhadap Kemampuan Berpikir Kreatif Siswa dalam Belajar Matematika. Jurnal Ilmiah Pendidikan Matematika Al-Qalasadi, 4(1), 31-36.

[2] Nurhayati \& Novianti. 2020. Pengaruh SPSS Terhadap Hasil Belajar pada Materi Statistika Deskriptif. AKSIOMA: Jurnal Program Studi Pendidikan Matematika, 9(1), 101-107.

[3] Riyanto, S., \& Nugrahanti, F. 2018. Pengembangan Pembelajaran Statistika Berbasis Praktikum Aplikasi Software SPSS dengan Bantuan Multimedia untuk Mempermudah Pemahaman Mahasiswa terhadap Ilmu Statistika. DoubleClick: Journal of Computer and Information Technology, 1(2), 62-67.

[4] Hayat, Syaipul, M., Anggraeni, S \& Redjeki, S. 2012. Pembelajaran Berbasis Praktikum Pada Konsep Invertebrata Untuk Pengembangan Sikap Ilmiah Siswa. Bioma, 2(2), 141-752.

[5] Komang I. G. 2012. Pengaruh Penerapan Model Pembelajaran Kooperatif Dengan Teknik Tutor Sebaya Berbantuan Picture and Picture Terhadap Hasil Belajar Tik Mahasiswa Kelas VII Semester Ganjil SMP Negeri 1 Sukasada Tahun Ajaran 2011/2012. KARMAPATI: Kumpulan Artikel Mahasiswa Pendidikan Teknik Informatika, 1(3), 376-387.

[6] Ahdiyat, M., \& Sarjaya. 2014. Metode Tutor Sebaya untuk Meningkatkan Hasil Belajar Matematika pada Materi Pengolahan Data. Jurnal Formatif, 4(1), 71-79.

[7] Abineneo, P., Rowa, Y. Rina., \& Jagom, Y. O. (2019). Pengaruh Model Pembelajaran Tutor Sebaya Terhadap Prestasi Belajar Matematika Siswa. ASIMTOT: Jurnal Kependidikan Matematika, 1(1), 61-67.

[8] Putra, L. V., Purwanti, K. Y., \& Khoiriyah, I. S. A. 2018. Pembelajaran Matematika Model Tutor Sebaya dengan Strategi Heuristik Vee. JANACITTA: Journal of Primary and Children's Education, 1(2), 38-44.

[9] Pangerti, B. 2015. Pengaruh Metode Pembelajaran Tutor Sebaya terhadap Motivasi Belajar, Minat Belajar dan Hasil Belajar Matematika Kelas XI Ilmu Alam MAN Model Sorong. Jurnal Ilmu Pendidikan Indonesia, 3(1), 30-39.

[10] Izzati, N. 2015. Pengaruh Penerapan Program Remedial Dan Pengayaan Melalui Pembelajaran Tutor Sebaya terhadap Hasil Belajar Matematika Siswa. EduMa, 4(1), 54-68.

[11] Setyanto, A., E. 2013. Memperkenalkan Kembali Metode Eksperimen dalam Kajian Komunikasi. Jurnal Ilmu Komunikasi, 3(1), 37-48. 